\title{
Biodegradation of Solid Wastes of Agar Seaweed Processing Industry by indigenous cellulolytic Bacillus Pumilus LA4P
}

\author{
Ifah Munifah $^{1}$, Titi Candra Sunarti ${ }^{2}$, Hari Eko Irianto ${ }^{3}$ and Anja Meryandini ${ }^{1}$ \\ ${ }^{1}$ Department of Biology, Faculty of Mathematics and Natural Sciences, \\ Institut Pertanian Bogor, Dramaga Campus, Bogor 16680, Indonesia. \\ ${ }^{2}$ Department of Agroindustrial Technology, Faculty of Agricultural Engineering \\ and Technology, Bogor Agricultural University, Bogor 16680, Indonesia. \\ ${ }^{3}$ Research center for Fisheries Management and Conservation
}

DOI: http://dx.doi.org/10.13005/bbra/1862

(Received: 14 August 2015; accepted: 16 October 2015)

\begin{abstract}
Indonesia is known as second seaweed producer in the world after China. Gracilaria sp seaweed is important commodity in industry, as raw material to produce agar and it derivate products. Solid wastes of agar seaweed processing industry contain considerable amounts of cellulose. It can effectively be utilized either as a major source of energy feedstock or as a $r$ aw material for production of high value product. Here, hundreds of cellulolytic bacteria were screened and isolated from solid wastes of agar seaweed processing industry. Among the isolates, LA4P strains showing higher potential for practical uses were purified on solid wastes of agar seaweed processing Industry; (SWA) agar plates and identified as Bacillus pumilus strains by morphological, physiological, and biochemical characterization and 16S rRNA gene analysis. The production patterns of cellulose degrading enzymes were investigated during cell culture. The isolated strains produced CMCase, Avicelase, â-glucosidase, and cellobiase enzymes, which suggested synergic cellulolytic systems in Bacillus pumilus LA4P.
\end{abstract}

Key words: Solid waste, cellulolytic bacteria, Bacillus pumilus.

Seaweed is a source of abundant biomass and renewable, so it can be used as an alternative raw material for bioenergy production, and often referred to as the third generation biomass ${ }^{1,2,3}$. Seaweeds have significant differences with land plants, both on the chemical composition, physiology, and morphology. Carbohydrate composition of macroalgae quite abundant and varied, the percentage of carbohydrates seaweed green, red, and brown, respectively by $25-50 \%$, $30-60 \%$, and $30-50 \%{ }^{4}$. Prospects of seaweed processing industry is still not matched by handling the processing of solid waste.

Gracilaria verrucosa, red seaweed has

\footnotetext{
* To whom all correspondence should be addressed.

E-mail: ifah_munifah@yahoo.com.au ameryandini@ipb.ac.id
}

been used for production of agar and bioethanol 3,5 . The algae harvested at various time durations resulted in extraction of 27-33\% agar. The leftover pulp was found to contain $62-68 \%$ holocellulose, which on enzymatic hydrolysis was done using commercial cellulase from Trichoderma reesei (ATCC 26921) and â-glucosidase from Aspergillus niger (Novozyme 188) were yielded $0.87 \mathrm{~g}$ sugars/ $\mathrm{g}$ cellulose. The enzymatic hydrolysate on fermentation with Saccharomyces cerevisiae produced ethanol with an ethanol yield of $0.43 \mathrm{~g} / \mathrm{g}$ sugars. The mass balance evaluation of the complete process demonstrates that developing biorefinery approach for exploiting Gracilaria verrucosa, a red alga, could be commercially viable. As with cellulose in land plants, seaweed also has cellulose. On land plants, cellulose fraction is 
greatest fraction range of $30 \%$ to $50 \%$ of the total, while the seaweed fraction of cellulose ranges between $2-23 \%$ variable follow its kind ${ }^{6}$.

Cellulose is generally found in plant cell walls and have a difficult degraded nature. It makes only a few of microorganisms capable degrading plant cell walls to be able to hydrolyze cellulose. Bacteria and fungi can not use this cellulose directly, therefore they secrete cellulase. Anaerobic bacteria, will secrete selulosom will stick them on the surface of cellulose ${ }^{7}$.

Cellulose is a carbohydrate that is abundant in nature. It is a linear polysaccharide composed of glucose units bound repetition at 1.4 acetal bond and forms a major component of cell walls both in higher plants as well as a low level. Cellulose is one of an abundant natural biopolymer which is renewable and has potential to converse become value added product. It can be biodegraded by cellulase produced by cellulolytic microbe. In recent years, it has developed cellulosic biomass (cellulose and hemicellulose), such as processing of agricultural and forest waste, waste paper, and seaweed processing industry waste as a source of sugar, for further fermented into ethanol. Seaweed is a potential source of cellulosic material and is very useful as a raw material. Cellulose was first extracted from seaweed of the class Valonia, Halicystis, Cladophora and also some brown seaweed. Cellulose crystal in nature contained as a mixture of two crystalline cellulose $\alpha$ (as chain has a triclinic structure) and cellulose $\alpha$ (as two chain monoclinic structure). Cellulose derived from algal species consisting of porous cellulose hollow like a network that sets it apart from plant cellulose ${ }^{8}$.

Several previous studies hydrolysis waste seaweed have been done using a strong acid, thermal treatment, a commercial enzyme, and the addition of cultured yeasts Trichoderma resei, Saccharomyces cerevisiae ${ }^{3,9,10,11,12,13}$. Commercial enzyme and microbial cultures are relative expensive and also difficult to get, therefore the process of hydrolysis will be economic if using the enzyme production from process utilizing local raw material as substrat. The high cost of substrat is generally limiting factor in the production of the enzyme ${ }^{14}$, therefore the selection of low cost substrate becomes very important. The application of cellulolytic bacteria to degrade seaweed solid waste is seen as a strategy to produce valuable product from solid wastes of agar seaweed processing Industry. This study aims to utilize solid wastes of agar seaweed processing industry as source of indigenous cellulolytic and as a substrate for the production of cellulase enzymes.

\section{MATERIALSAND METHOD}

\section{Sources of strain}

Bacterial strain, Bacillus pumilus LA4P, isolated from decaying industrial solid seaweed processing wastes (agar) Malang, East Java. It was cultured in a medium containing SWA or CMC as substrat $10 \mathrm{~g} / \mathrm{L} ; \mathrm{KH}_{2} \mathrm{PO}_{4} 1.0 \mathrm{~g} / \mathrm{L} ; \mathrm{MgSO}_{4} .7 \mathrm{H}_{2} \mathrm{O}$ $0.5 \mathrm{~g} / \mathrm{L} ; \mathrm{NaCl} 0.5 \mathrm{~g} / \mathrm{L} ; \mathrm{FeSO}_{4} .7 \mathrm{H}_{2} \mathrm{O} 0.01 \mathrm{~g} / \mathrm{L}$; $\mathrm{MnSO}_{4} \cdot \mathrm{H}_{2} \mathrm{O} 0.01 \mathrm{~g} / \mathrm{L} ; \mathrm{NH}_{4} \mathrm{NO}_{3} 0.3 \mathrm{~g} / \mathrm{L}$; SWAS $10.0 \mathrm{~g} / \mathrm{L}$; Agar $12.0 \mathrm{~g} / \mathrm{L}$.

\section{Source of substrat SWA}

Solid waste of agar seaweed processing industry was choosen as the carbon substrate in this study because their abundance in agar's industry. It was collected from CV.Agar Sari Malang, East Java, Indonesia. Solid seaweed wastes were ground, sieved through a $2 \mathrm{~mm}$ screen for uniform particle size, and stored at $2^{\circ} \mathrm{C}$ for further use. The final size of the samples was 200 mesh (75 $\mu \mathrm{m})$.

\section{Growth curve}

Bacillus pumilus LA4P was grown in broth medium containing SWA as major carbon source. Liquid culture were grown with vigorous aeration $120 \mathrm{rpm}$ at $37^{\circ} \mathrm{C}$. Growth was monitore by total plate count and activity measurement per 12 hours. Bacillus pumilus LA4P was also grown in broth medium containing $\mathrm{CMC}$ broth medium, and growth was monitore by optical density $(600 \mathrm{~nm})$.

\section{Determination of optimum concentration SWA as} major carbon source

To determine optimum concentration of SWA as carbon source, starter cultures were prepared by transferring Bacillus pumilus LA4P cells with an inoculation loop from the SWA agar plates to $100 \mathrm{~mL}$ of SWA liquid medium, at various concentration $0,5 \% ; 1 \%, 1,5 \% ; 2 \% ; 2,5 \%$; and $3 \%$ SWA as major carbon source. The initial $\mathrm{pH}$ of which was adjusted to 7.0 , in $500 \mathrm{~mL}$ Erlenmeyer flasks. The flasks were further incubated on a shaker at $150 \mathrm{rpm}$ for 8 days at $37^{\circ} \mathrm{C}$. Culture samples were taken every $24 \mathrm{~h}$ during incubation, and their cell free supernatants were obtained by 
centrifugation $(10,000 \times \mathrm{g}, 10 \mathrm{~min})$ and analyzed for cellulolytic activities.

\section{Production Cellulolytic Enzyme Solutions.}

Starter cultures were prepared by transferring cells with an inoculation loop from the SWA agar plates to $100 \mathrm{~mL}$ of $2.5 \%$ SWA liquid medium, the initial $\mathrm{pH}$ of which was adjusted to 7.0 if not specified, in 500mL Erlenmeyer flasks. Four days after shaking incubation at $37^{\circ} \mathrm{C}$, aliquots of $2 \mathrm{~mL}$ starter cultures were seeded into $200 \mathrm{~mL}$ of SWA liquid medium in $500 \mathrm{~mL}$ flasks. The flasks were further incubated on a shaker at $150 \mathrm{rpm}$ for 4 days at $37^{\circ} \mathrm{C}$. Supernatant were obtained by centrifugation $(10,000 \times \mathrm{g}, 5 \mathrm{~min})$ and assayed for cellulolytic enzyme activities at various $\mathrm{pH}$ and certain temperature to determine stability.

\section{Enzyme Activity Assay}

CMCase activity was measured by incubating $0.2 \mathrm{~mL}$ of enzyme solution with $0.5 \mathrm{~mL}$ of $1 \%(\mathrm{w} / \mathrm{v})$ carboxymethyl cellulose, prepared in $0.1 \mathrm{M}$ sodium acetate buffer ( $\mathrm{pH} 5.0$ ), and $0.3 \mathrm{~mL}$ of $0.1 \mathrm{M}$ sodium acetate buffer ( $\mathrm{pH} 5.0$ ) for $10 \mathrm{~min}$ at $50 æ \% \mathrm{C}$. The reducing sugars liberated were estimated by the 3,5-dinitrosalicylic acid (DNS) method. The enzyme reaction was stopped by the addition of $3 \mathrm{~mL}$ DNS reagent (dinitrosalicylic acid $1 \mathrm{~g}, \mathrm{NaOH}, 16 \mathrm{~g}$, potassium sodium tartarate $300 \mathrm{~g}$, and distilled water up to $1 \mathrm{~L}$ ) to the above $1 \mathrm{~mL}$ reaction mixture, boiled in capped glass tubes for 5 $\mathrm{min}$, and cooled in cold water, and then optical density was measured at $540 \mathrm{~nm}$. The CMCase activity was determined using a calibration curve for D-glucose. One unit of CMCase activity was defined as the amount of enzyme that released 1 $\mu \mathrm{mol}$ of reducing sugars as glucose equivalents $\min ^{-1}$.

\section{pH optimum of crude enzyme}

To estimate the $\mathrm{pH}$ optimum of crude enzyme, activity was measured using $1 \%(\mathrm{w} / \mathrm{v})$ $\mathrm{CMC}$ as the substrate at $50{ }^{\circ} \mathrm{C}$ in $100 \mathrm{mM}$ citrate

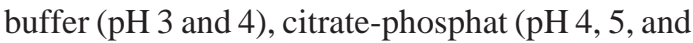
6), bufer phosphate ( $\mathrm{pH} 6,7$, and 8), bufer borate (pH 9 and 10). The crude enzyme stability at different $\mathrm{pH}$ level was determined by measuring the activity after incubating the enzymes for 60 minutes at $500 \mathrm{C}$ at $\mathrm{pH} 3.0$ to $\mathrm{pH} 10$. After preincubation, the enzyme solution was subjected to the normal cellulase assay using DNS method's. Optimum Temperature of crude enzyme

Optimum temperature of crude enzyme
Bacillus pumilus LA4P was determined. To $500 \mu \mathrm{L}$ of $1 \%$ CMC in $20 \mathrm{mM}$ phosphate buffer ( $\mathrm{pH} 7.0$ ), $500 \mu \mathrm{L}$ of appropriate concentration of enzyme were added and incubated at various temperatures $\left(0,20,30,40,50,60,70,80,90^{\circ} \mathrm{C}\right)$ for $30 \mathrm{~min}$. The activity was then measured to DNS method.

\section{Stability temperature of crude enzyme}

Enzyme stability of crude enzyme Bacillus pumilus LA4P was studied over the temperature range of 30 to $80^{\circ} \mathrm{C}$. Stability temperature of crude enzyme was determined using standard CMC assay. The crude enzyme from Bacillus pumilus LA4P was incubated in $100 \mathrm{mM}$ potassium phosphate buffer, $\mathrm{pH}$ 7.3, for 15 minutes at different temperatures and then added to $500 \mu \mathrm{L}$ of $1 \%$ CMC in $20 \mathrm{mM}$ phosphate buffer ( $\mathrm{pH}$ 7.0). The enzyme activity was then measured according to DNS method.

\section{Substrate Specifity}

Hydrolytic ability from Bacillus pumilus LA4P against $0.1 \%(\mathrm{w} / \mathrm{v})$ agar, solid waste of agar industry (SWA), Avicel, cellobiosa, xylan, filter paper (FP), CMC, and p-nitrophenol â-Dglucopyranoside (pNPG) in $20 \mathrm{mM}$ phosphate buffer ( $\mathrm{pH} 7$ ) were determined to evaluate substrate specifity of crude enzyme.

Avicelase activity was measured by incubating $0.5 \mathrm{~mL}$ of enzyme solution with $0.1 \%$ (w/v) of Avicel, a microcrystalline cellulose, as substrate and $1.5 \mathrm{~mL}$ of $0.1 \mathrm{M}$ sodium acetate buffer (pH 5.0) for $1 \mathrm{~h}$ at $50^{\circ} \mathrm{C}$. After incubation, the reaction mixture was centrifuged at $10,000 \times \mathrm{g}$ for $5 \mathrm{~min}$, and then $1 \mathrm{~mL}$ of the supernatant was taken to determine reducing sugars by the DNS method. One unit of Avicelase activity was defined as the amount of enzyme that released $1 \mu \mathrm{mol}$ of reducing sugars as glucose equivalents $\mathrm{min}^{-1}$.

Filter paper-hydrolytic (FPase) activity was measured by a procedure in which Whatman no. 1 filter paper was used as a substrate. Fifty milligrams of the substrate suspended in $1.5 \mathrm{~mL}$ of 0.1 Msodium acetate buffer ( $\mathrm{pH}$ 5.0) was incubated with $0.5 \mathrm{~mL}$ of enzyme solution at $50^{\circ} \mathrm{C}$ for $2 \mathrm{~h}$. After incubation, the reaction mixture was centrifuged at $10,000 \times \mathrm{g}$ for $5 \mathrm{~min}$, and then $1 \mathrm{~mL}$ of the supernatant was taken for the determination of reducing sugars by the DNS method. One unit of FPase activity was defined as the amount of enzyme that released $1 \mu \mathrm{mol}$ of reducing sugars as glucose equivalents $\mathrm{min}^{-1}$. $\beta$-glucosidase (or 
cellobiase) activity was measured by using $\rho$ nitrophenyl- $\beta$-D-glucopyranoside (pNPG) as a substrate. The hydrolysis of pNPG releases $\rho$ nitrophenol, a pigmented substance that can be measured spectrophotometrically at $400 \mathrm{~nm}$. The reaction mixture, containing $0.5 \mathrm{~mL}$ of $1 \mathrm{mg} / \mathrm{mL}$ pNPG, $0.5 \mathrm{~mL}$ of 0.05 Msodium acetate buffer $(\mathrm{pH} 5.0)$, and $0.5 \mathrm{~mL}$ of enzyme solution, was incubated at $50^{\circ} \mathrm{C}$ for $1 \mathrm{~h}$. The enzyme reaction was stopped by adding $2 \mathrm{~mL}$ of $1 \mathrm{M} \mathrm{Na}_{2} \mathrm{CO}_{3}$, and the absorbance was measured at $400 \mathrm{~nm}$. One unit of â-glucosidase activity was defined as the amount of enzyme that released $1 \mu \mathrm{mol}$ of para-nitrophenol min ${ }^{\mathrm{s}}$.

\section{Analysis of product hydrolysis using thin layer chromatography}

Bacillus pumilus LA4P was grown in broth medium containing $2.5 \%(\mathrm{w} / \mathrm{v})$ solid wastes of agar seaweed processing Industry (SWA) as major carbon source. Liquid culture were grown with vigorous aeration $120 \mathrm{rpm}$ at $37^{\circ} \mathrm{C}$. Supernatant as product of hydrolysis of SWA were collected every 24 hours. Samples were centrifuge to remove the insoluble SWA. This followed by an analyzed using HPLC and thin layer chromatography. The supernatant were performed on Silica Gel F254 HPTLC plates (Merck) to detect carbohydrates, plate were developed with 2:1:1 n-butanol:acetic acid:water solution, air dried and then heat at $110{ }^{\circ} \mathrm{C}$. Degradation products were visualized by UV lamp at 254nm.

\section{Analysis of product hydrolysis using HPLC}

The supernatant (crude enzyme) from Bacillus pumilus LA4P were vacuum filtered to removed contaminants using 0,2 um fiter (Millipore) into glass vials and analyzed for monomeric and oligomeric sugars. The sugar analysis was performed in an Agilent 1200 High Pressure Liquid Chromatography (HPLC), fitted with Agilent HiPlex H, $7.7 \times 300 \mathrm{~mm}, 8 \mu \mathrm{m}$. The column temperature was maintained at $80^{\circ} \mathrm{C}$ and RID was maintained $55^{\circ} \mathrm{C}$ during analysis. The mobile phase uses was $0.005 \mathrm{M} \mathrm{H}_{2} \mathrm{SO}_{4}$ in water HPLC filtered. Gradient Isocratic, flow rate $0.7 \mathrm{~mL} / \mathrm{min}$, injection volume was $20 \mu \mathrm{L}$. The standard solutions and sugar consist of glucose, xylose, cellobiose, cellotriose, and cellotetraose.

\section{RESULTAND DISCUSSION}

The initial and the most important step for developing an industrial process for the production of large quantity of enzyme is potential strains. Halo zone formation on agar medium is a qualitative measure of extracellular cellulose enzyme production by cellulolytic microorganisms ${ }^{15}$. Although initially research of cellulase was mainly on fungi, now a day increasing interestin cellulase production by bacteria because the bacteria have fast grow rate. Figure 2 shows that isolates LA4P cellulase enzyme activity is relatively more potent than other isolates in plate agar. The diameter of the halo zone is very useful for predicting the enzyme yield, as an aid to select strain with high level of polysaccharide (such as cellulose) degrading activities ${ }^{15}$.

Table 1. Biochemical characteristics of LA4P strains

from solid waste of agar seaweed processing industry

\begin{tabular}{lccc}
\hline Characteristic & Result & Substrat Utilization & Result \\
\hline Amylase & + & D-Glucose & + \\
protease & + & L-arabinose & + \\
lipase & + & D-xylose & + \\
phosphatase & - & D-mannitolGalactose & + \\
Dnase & - & Fructose & + \\
Gelatinase & + & Mannose & + \\
Chitinase & + & Nitrate & + \\
Growth temperature & room & Adonitol & - \\
oxidase & + & Dulcitol & - \\
catalase & + & Sorbitol & - \\
indole production & - & Inositol & - \\
Voges proskauer & + & Urea & \\
citrate utilization & - & & \\
\hline
\end{tabular}


Morphological examination showed the colour white, round irregular colony shape, surface colonies smooth, lobate colony edge, and shiny smooth colony appearance, indicating that the species is aerobic. Microscopically, this strain was found to be a gram positive motile bacillus (Figure 2a). Malachite green staining showed oval spore at the central endospore of bacteria (Figure 2b).

The growth curve in Fig. 3b indicated the presence of cellulose activity in both supernatant from broth CMC media and broth SWA media as seen in fig. $3 \mathrm{~b}$ and table 3 ,optimum incubation time Bacillus pumilus LA4P in broth CMC media
(60 hours) relative shorter than broth SWA media (108 hours). Carboxylmethylcellulose is soluble substrate, while SWA is complex insoluble substrate. The complicity structured cause incubation time longer than in soluble substrate.

The effect of concentration solid waste of agar seaweed processing industry (SWA) as carbon source was studied ranges from $0.5 \%$ to $3 \%$ in SWA broth. The concentration of SWA plays a critical role in enzyme yield in production media. The media was inoculated with different concentration SWA and incubated at $37^{\circ} \mathrm{C}$ for 7 days. The optimum enzyme production observed

Table 2. Cellulase activity of Bacillus pumilus LA4P in SWA and CMC broth

\begin{tabular}{ccccccc}
\hline \multirow{2}{*}{ Iisolate } & \multicolumn{3}{c}{ Activity } & & \multicolumn{2}{c}{ Optimum incubation time } \\
\cline { 2 - 3 } \cline { 5 - 6 } & CMC (U/mL) & SWA $(\mathrm{U} / \mathrm{mL})$ & & CMC (jam) & SWA (jam) \\
\hline LA4P & 0.200317 & 0.25843755 & & 60 & 108 \\
\hline
\end{tabular}

Table 3. Effect of concentration solid waste of agar seaweed processing industry (SWA) as carbon source

\begin{tabular}{lcc}
\hline $\begin{array}{l}\text { \% SWA } \\
\text { substrat }\end{array}$ & $\begin{array}{l}\text { Incubation } \\
\text { time (day) }\end{array}$ & $\begin{array}{c}\text { Activity } \\
\text { ( U/mL) }\end{array}$ \\
\hline 0.5 & 5 & 0.201318743 \\
1 & 5 & 0.202321 \\
1.5 & 2 & 0.197310406 \\
2 & 3 & 0.171757255 \\
2.5 & 4 & 0.343614719 \\
3 & 6 & 0.200316659 \\
\hline
\end{tabular}

Table 4. Substrat specifity of cellulolytic crude enzyme from Bacillus pumilus LA4P

\begin{tabular}{ll}
\hline $0.1 \%$ Substrates & Activity $(\mathrm{U} / \mathrm{mL})$ \\
\hline Agar & 0.088033 \\
SWA & 0.127364919 \\
Avicel & 0.118596681 \\
cellobiosa & 0.142997435 \\
Xylan & 0.007365 \\
FP & 0.026505131 \\
CMC & 0.134379509 \\
pNpG & 0 \\
\hline
\end{tabular}

Table 5. Retention time TLC and HPLC of hydrolysis product

\begin{tabular}{|c|c|c|c|c|c|c|c|}
\hline \multirow{2}{*}{$\begin{array}{l}\text { P 2.5\% } \\
\text { standar }\end{array}$} & \multicolumn{4}{|c|}{ Rf TLC } & \multicolumn{3}{|c|}{ Retention time HPLC } \\
\hline & & Rf TLC standar & Rf1 & Rf2 & Rf3 & tR standar & $\mathrm{tR} 1 \mathrm{tR} 2 \mathrm{tR} 3$ \\
\hline G1 & $0.55-0.64$ & & & & 9.761 & & \\
\hline G2 & $0.41-0.52$ & & & & 8.296 & & \\
\hline G3 & $0.27-0.41$ & & & & 7.69 & & \\
\hline G4 & $0.21-0.33$ & & & & 7.429 & & \\
\hline G5 & $0.16-0.20$ & & & & 7.317 & & \\
\hline \multicolumn{8}{|l|}{ Day 1} \\
\hline Day 2 & & $0.27-0.40(\mathrm{G} 3)$ & & & & 7.769 & \\
\hline Day 3 & & $0.27-0.40(\mathrm{G} 3)$ & & & & 7.924 & \\
\hline Day 4 & & $0.27-0.40(\mathrm{G} 3)$ & $0.41-0.49$ (G2) & $0.53-0.62$ (G1) & & 7.975 & 8.379 .675 \\
\hline Day 5 & & $0.30-0.36$ (G3) & $0.37-0.50(\mathrm{G} 2)$ & $0.54-0.63$ (G1) & & 7.975 & 8.379 .675 \\
\hline Day 6 & & $0.41-0.48$ (G2) & $0.55-0.62(\mathrm{G} 1)$ & & & 8.229 & 9.68 \\
\hline Day 7 & & $0.55-0.62(\mathrm{G} 1)$ & & & & 9.683 & \\
\hline
\end{tabular}




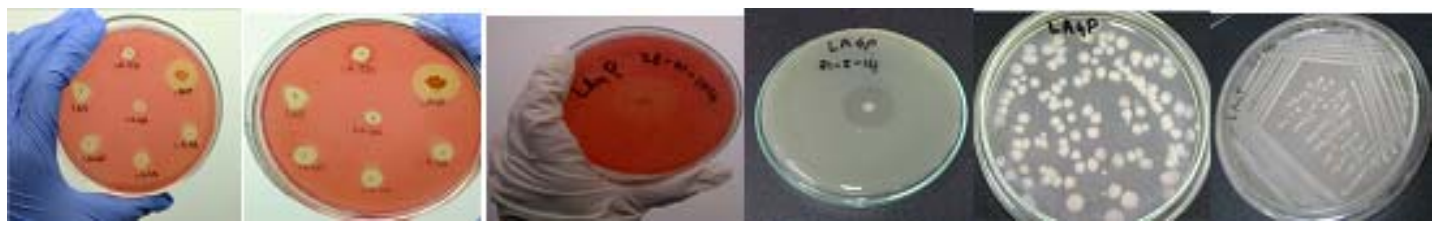

Fig. 1. Screening for cellulolytic activity of Bacillus pumilus LA4P, photo image of clearing zone around colony of cellulolytic bacteria on SWA agar after 5 days

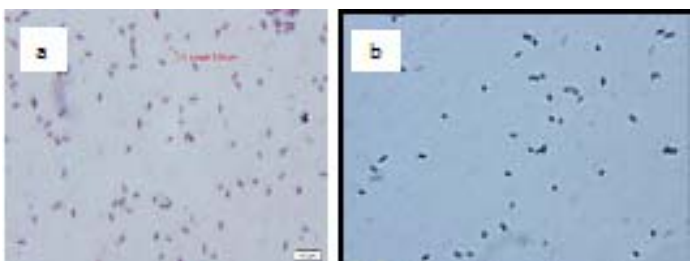

Fig. 2. Morphological identification of cellulolytic bacterium

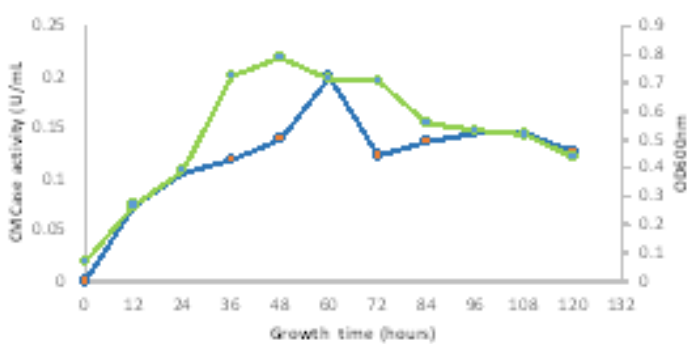

Fig. 3(a). Growth curve of Bacillus Pumilus LA4P

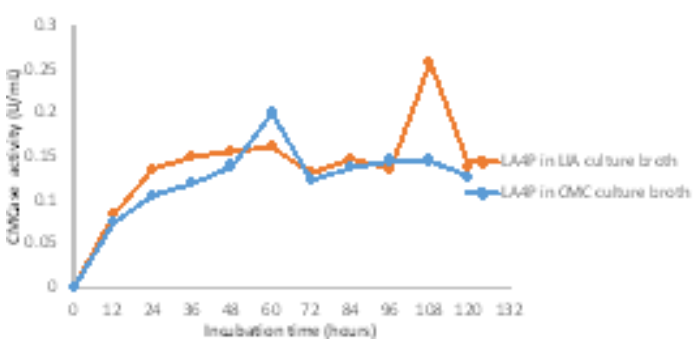

Fig. 3(b). Time course of cellulase production from Bacillus Pumilus LA4P in different media

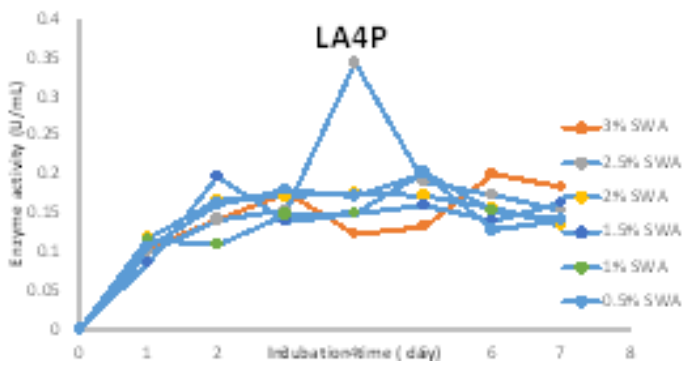

Fig. 4. Effect of different concentration source carbon on enzyme production by Bacillus pumilus in SWA concentration range from $1.5 \%$ to $2.5 \%$ of SWA (Fig. 4 ). The maximum production obtained in $2.5 \%$ SWA $(0.3436 \mathrm{U} / \mathrm{mL})$.

\section{Substrat specifity}

The crude enzyme showed highest activity against cellobiose and CMC. There was almost no hydrolysis ability against aubstrates of xylan, filter paper and p-NPG. It was, accordingly considered the crude cellulose from Bacillus pumilus LA4P to be an endo-1,4-glucanase and cellobiohidrolase. The enzyme endo 1,4 $\beta$ and $\alpha$ glucosidase -glukanase work synergistically to degrade cellulose to glucose. Exo $1.4 \beta$-glukanase enzyme cut off the tip of cellulose chains crystalline into reducing sugars after endo 1,4 $\beta$-glukanase enzyme cut the amorphous site.

A reducing sugar would bound to DNS solution (dinitro salicylic acid) which produces an orange color. The greater the amount of reducing sugars produced increasingly concentrated color pereaksinya. The absence of activity paperase filters because very little possibility of enzyme activity 1.4 exo $\beta$-glukanase produced by Bacillus pumilus LA4P isolates. Each enzyme cellulase has specificity of the structure around the substrate. Differences in the specificity of the enzyme endoglucanase and cellobiohidrolase is not absolute because both enzyme can hydrolyze $\beta$ 1,4 glucoside bond of amorphous cellulose. Determination of cellulase enzyme activity would be difficult if the filtrate to be measured enzyme activity is a mixture of various cellulase enzymes. Enzymes are not only able to hydrolyze the same substrate but also can work synergistically broke the same substrate, causing the measured activity is influenced by the proportion of each enzyme.

The predominant activity in crude enzyme from Bacillus pumilus LA4P was cellobiohidrolase, but the crude enzyme also displayed carboxymethylcellulase (CMCase), avicelase, and hydrolysis well SWA substrat.

Temperature and $\mathrm{pH}$ were important 
parameters that influenced enzyme activites. Temperature and $\mathrm{pH}$ of the enzyme depends on the type and source of enzyme. Determination of optimum $\mathrm{pH}$ and temperature was intended to obtain the proper $\mathrm{pH}$ and temperature, in which the enzyme works with the highest activity. The test resulted that crude enzyme from Bacillus pumilus has a relatively high activity in the $\mathrm{pH}$ range 6-8 buffer at $0.23 \mathrm{U} / \mathrm{mL}$ and a temperature of $40^{\circ} \mathrm{C}$. Activity of enzyme tend to increases in proportion to the increase in incubation temperature and reaches a maximum value at $40^{\circ}$ C. Information of temperature and $\mathrm{pH}$ optimum the activity of this enzyme is very useful for the application of this enzyme due to the material to be hydrolyzed.
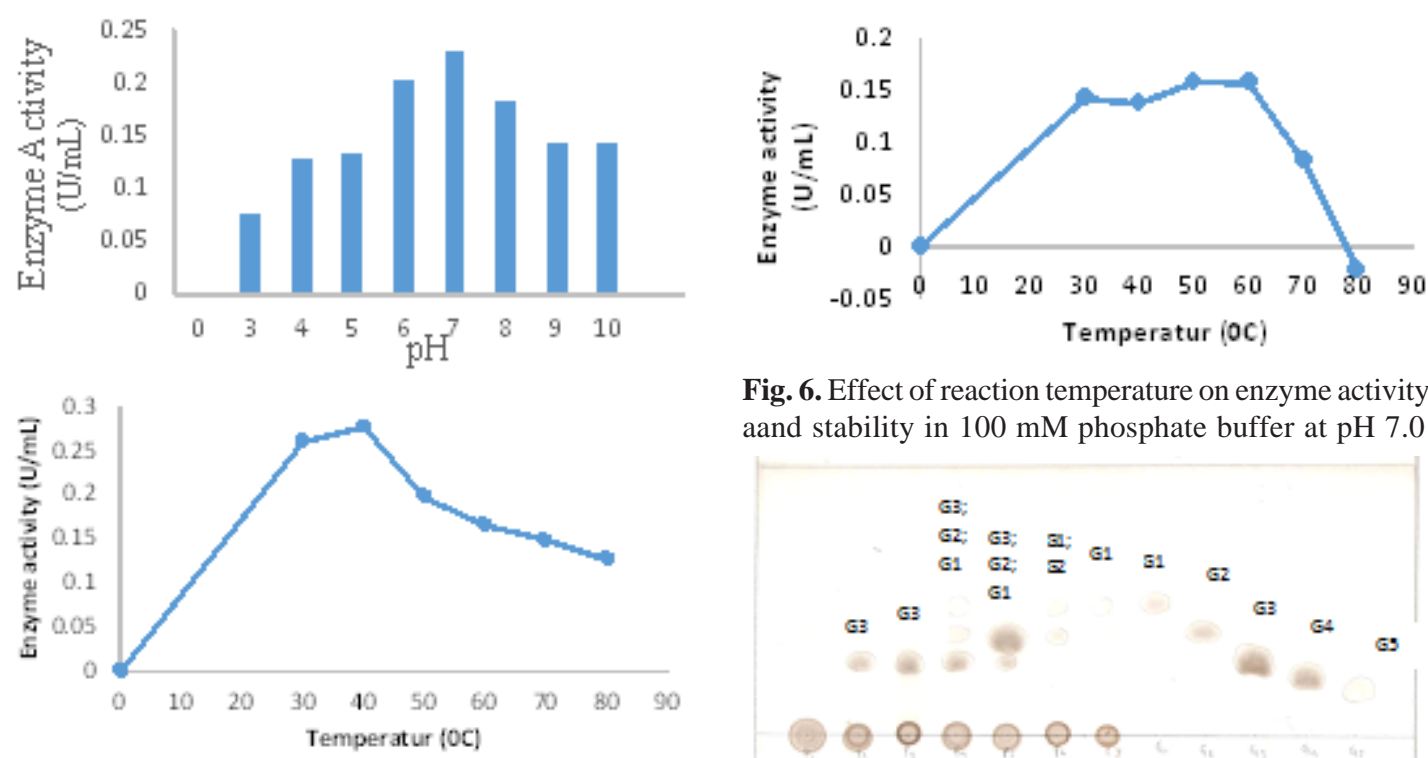

Fig. 6. Effect of reaction temperature on enzyme activity aand stability in $100 \mathrm{mM}$ phosphate buffer at $\mathrm{pH} 7.0$

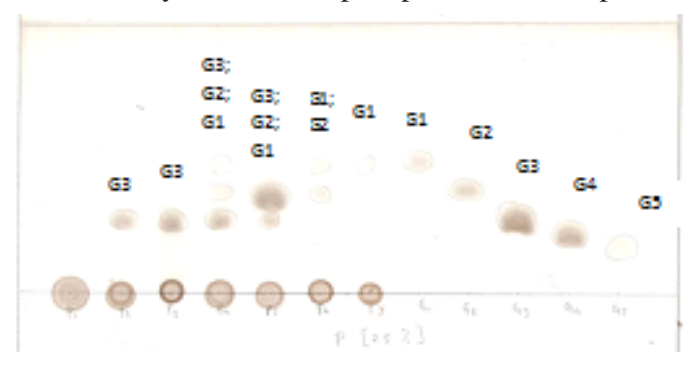

Fig. 5. Effect $\mathrm{pH}$ and temperature on enzyme activity by Bacillus Pumilus LA4P in enzyme production media containing SWA as carbon source

Fig. 7. Thin layer chromatogram oligosaccharides produced by LA4P. Symbols; G1; glucose; G2 : cellobiose, G3; Cellotriose, G4; cellotetraose, G5; Cellopentaose

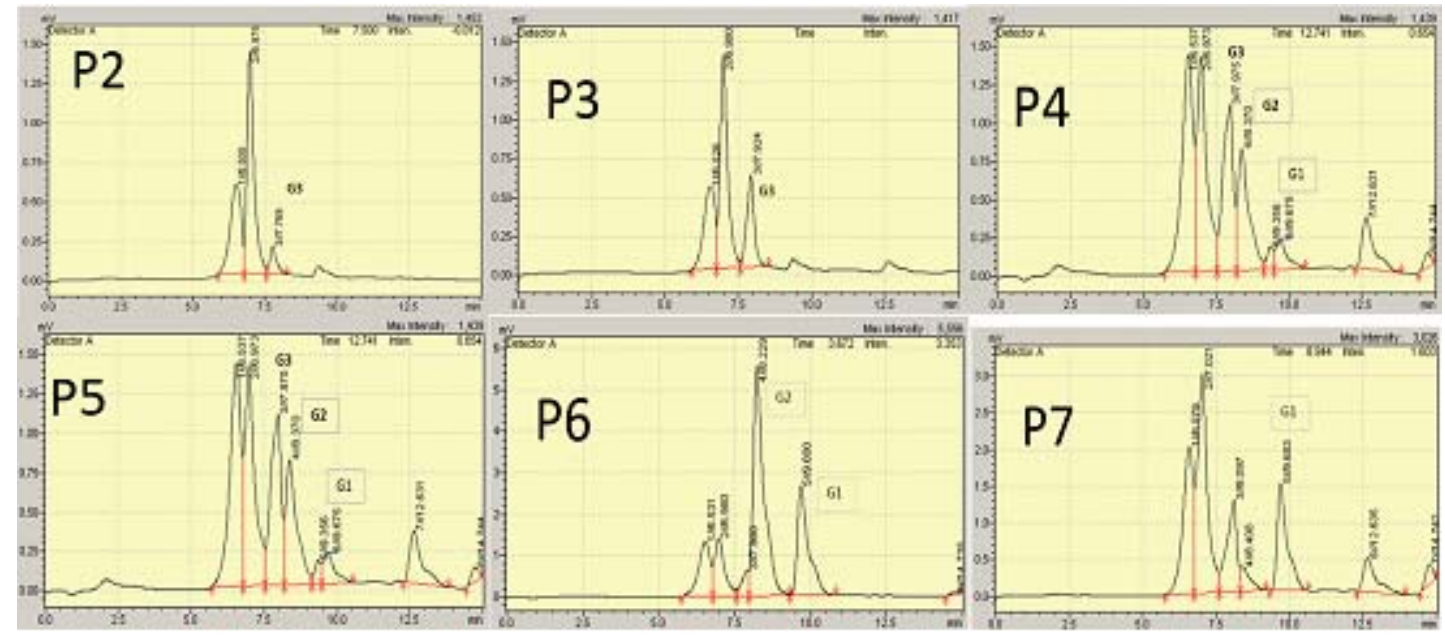

Fig. 8. HPLC of hydrolysis product of cellulose by Bacillus pumilus LA4P incubation time for $2-7$ day 


\section{Stability temperature of crude enzyme}

Thermal stability constitutes a very important property when intend to apply the industrial importance. Thermostability study of crude enzyme from LA4P was assessed by incubating the crude enzyme at range temperature $30-80^{\circ} \mathrm{C}$ for 15 minutes of incubation. The crude enzyme from Bacillus pumilus LA4P was incubated in $100 \mathrm{mM}$ potassium phosphate buffer, $\mathrm{pH} 7.0$, for 15 minutes at different temperatures and then added to $500 \mu \mathrm{L}$ of $1 \% \mathrm{CMC}$ in $20 \mathrm{mM}$ phosphate buffer ( $\mathrm{pH}$ 7.0). The thermal stability assay indicated that the activity was stable at 30 to $60^{\circ} \mathrm{C}$.

From the TLC result in figure 6, it can be observed that the crude supernatant was able to degrade insoluble substrat SWA to form smaller products cellotriose in the second day of incubation time. Initially, after 48 hour very small amount of cellotriose (G3) were progressive formed during incubation. The product cellotriose could be seen increased with incubation time until $5^{\text {th }}$ day . After the $4^{\text {th }}$ and $5^{\text {th }}$ day incubation, it could be seen at TLC result and chromatogram HPLC, there is product hydrolysis as G3, G2 and small amount of G1.

\section{CONCLUSION}

Several microorganism have ability to convert cellulose become simple carbohydrates have been known for decades. These paper has presented a hydrolysis solid waste of agar seaweed processing industry (SWA) by indigenous cellulolytic Bacillus pumilus LA4P. Since pure commercialized cellulose is expensive as substrate, solid waste of agar seaweed processing industry (SWA) can be used as a good aalternative for cellulose production.

\section{REFERENCES}

1. Singh A, Nigam PS, Murphy JD., Mechanism and Challenges in Commercialisation of Algal biofuels. Biores Technol. 2011; 102:26-34.

2. Jang J, Cho Y, Jeong G, Kim S., Optimization of Sacharification and ethanol production by simultaneous saccharification and fermentation (SSF) from seaweed Saccharina japonica. Bioprocess Biosyst Eng. 2012; 35: 11-18

3. Kim HT, Yun EJ, Wang D, Chung JH, Choi IG,
Kim KH., High temperature and low acid pretreatment and agarase treatment of agarose for the production of sugar and ethanol from red seaweed biomass. Biores Technol. 2013; 136: 582-587

4. Jung KA, Lim SR, Kim Y, Park JM., Potentials of macroalgae as feedstocks for biorefinery. Biores Technol. 2013; 135: 182-190

5. Kumar, S., Gupta, R., Kumar, G., Sahoo, D., \& Kuhad, R. C., Bioethanol production from Gracilaria verrucosa, a red alga, in a biorefinery approach. Bioresource Technology, 2013; 135: 150-156. doi:10.1016/j.biortech.2012.10.120

6. Kim GS, Myung KS, Kim YJ, Oh KK, Kim JS, Ryu HJ, dan Kim KH., Methode of producing biofuel using sea algae. Seoul: World Intelectual Property Organization, 2008

7. Wilson DB., Microbial diversity of cellulose hydrolisis. Current Opinion in Microbiology. 2011; 14: 1-5.

8. Siddhanta AK, Prasad K, Meena R, Presad G, Mehta GK, Chhatabar MU., Profiling of cellulose content in Indian seaweed species. Biores Technol. 2009; 100: 6669-6673.

9. Kim YS, Chae SW, Park DH, Sunwoo C., Pretreatment of Gelidium amansii for the production of bioethanol. Bull. Korean Chem. Soc. 2010; 131: 511-517

10. Kim NJ, Li H, Jung K, Chang HN, Lee PC. Ethanol production from marine algal hydrolysates using Escherichia coli KO11. Biores Technol. 2011; 102: 7466-7470.

11. John RP, Anisha GS,Nampoothiri KM, Pandey A., Micro and macroalgal biomass: A renewable source for bioethanol. Biores Technol. 2011; 102: 186-193.

12. Yanagisawa M, Nakamura K, Ariga O, Nakasaki K., Production of high concentrations of bioethanol from seaweeds that contain easily hydrolyzable polysaccharides. Process Biochem. 2011; 46: 2111-2116

13. Ruiz HA, Jasso RM, Fernandes BD, Vicente AA, Teixeira JA., Hydrothermal processing, as an alternative for upgrading agriculture residues and marine biomass according to the biorefinery concept: A review. Renewable and Sustainable Energy Reviews. 2013; 21: 35-51.

14. Ariffin H, Hassan M, Shah UK, Abdullah N, Ghazali FM, and Shirai Y., Production of bacterial endoglucanase from pretreated oil palm empty fruit bunch by Bacillus pumilus EB3. J. Biosci Bioeng 2008; 106:231-236.

15. Saini, Jitendra Kumar, Tewari, L., Simultaneous Isolation and Screening of Cellulolytic Bacteria/ : Selection of Efficient Medium. Journal of Pure and Applied Microbiology, 2012; 6: 1339-1344. 